\title{
Air quality in a hospital environment
}

\author{
J. I. Macedo ${ }^{1}$, T. H. Kubota ${ }^{2}$, L. S. Matsumoto ${ }^{2}$, A. T. Giordani ${ }^{2}$, \\ A. M. M. Takayanagui ${ }^{3}$, A. A. Mendes ${ }^{3}$ \& D. A. Bertolini ${ }^{4}$ \\ ${ }^{1}$ Doctorate Program in Nursing, \\ Nursing School of Federal University of Minas Gerais, Brazil \\ ${ }^{2}$ Center of Biological Sciences and Health, \\ State University of Northern Paraná, Brazil \\ ${ }^{3}$ Nursing School of Ribeirão Preto, University of São Paulo, Brazil \\ ${ }^{4}$ Immunology Department, State University of Maringá, Brazil
}

\begin{abstract}
In recent decades, the contamination of the atmosphere has occupied a prominent place causing countless harm, making it a public health problem which jeopardises in a serious way the hospital environment, bringing a potential risk of hospital infection (HI). The aim of the study was to identify and classify hospital fungal contaminants in units of high complexity. The assessment of air quality was carried out in four categories of environment: High Complexity Intensive Care Adult Unit (AICU), Newborn (NICU), hallways and corridors and external area. The monitoring of these environments was conducted in the morning and afternoon, the air filters were removed and transferred to plates with culture media BDA and incubated at $28^{\circ} \mathrm{C}$, isolated and identified. Ten genera of filamentous fungi, pathogenic and toxigenic were found. It was found that, in the afternoon and in the morning, the contamination was significantly lower in AICU $\left(23.3 \mathrm{CFU} / \mathrm{m}^{3}\right)$, with $55.3 \mathrm{CFU} / \mathrm{m}^{3}$ in NICU. In none of the environments studied, the average concentration of filamentous fungi exceeded the maximum recommended by Resolution $\mathrm{N}^{\circ}$. 09 of the National Agency for Sanitary Vigilance of $750 \mathrm{CFU} / \mathrm{m}^{3}$.
\end{abstract}

Keywords: air quality, hospital units, fungi, infection.

\section{Introduction}

The health of individuals attending an environment in a health institution is closely related to the quality of the air they breathe. This is a relevant concern 
which brings us back to the early days of Florence Nightingale, who in the late nineteenth century instituted, as a routine for prevention and control of contamination of the hospital environment, the use of methods of hygiene and cleanliness in order to minimize the effects that micro-organisms in general entailed to patients, thereby providing a clean, clear and pleasant, free of dirt place, which would certainly contribute to the recovery of the ill people $[1,2]$.

According to Ordinance No. 2616 of May 13, 1998, the Ministry of Health defines hospital infection (HI), as "that acquired after the patient admission and manifested during hospitalization or even after discharge if this can be related to hospitalization or hospital procedures" [3].

Andrade and Angerami [2] reports that practices recommended for the control of infections acquired in hospitals prioritize the factors related to the environment and procedures in general.

In high-complexity hospitals providing care to critically ill patients in intensive care, environmental air quality directly influences the speed of recovery of patients and the occurrence of nosocomial infections due to the large supply of micro-organisms (environmental contaminants) which come from the outside air, the air conditioning system, construction, furniture, carpet, and especially of its occupants [1,3-5].

The contamination by airborne particles cause adverse consequences to individuals, especially infections, allergic and irritant reactions, which cause discomfort, disease, productivity loss and absenteeism by health professionals, among other adverse effects $[4,6]$.

Amongst the microorganisms suspended in the air, fungi are present in vast amounts as part of the air-biological ecosystem with rapid growth and great speed of multiplication and in extreme environmental conditions may cause disease in humans, animals and plants. The incidence of infections has increased in recent decades as HI units of high complexity then becoming a serious public health problem [7-9].

Under Resolution $\mathrm{N}^{\circ} .09$ of ANVISA, the recommended maximum amount of fungal contaminants in the air in hospitals is $750 \mathrm{CFU} / \mathrm{m}^{3}$ (colony forming units per cubic meter), which guarantees a minimum level of tolerance, and thereafter it is necessary that hospitals, through the Commission of Hospital Infection (CHI), conduct an adequate planning and management of the physical structure of the unit and the institution according to the current legislation in order to ensure patient safety and professional health [10].

This issue justifies the present study to identify the specific fungal environmental contaminants in a hospital to relate them to the notifications of $\mathrm{CCIH}$ propose measures to combat HI.

It's worth mentioning the HI determined by environmental contaminants caused by fungi, can prolong hospitalization, increase hospital costs and cause damage to the recovery of patients, families and professionals, and it's responsibility of the healthcare team to seek mechanisms to facilitate the prevention and control of HI.

Despite all specialties, there are patients who have multiple medical complications or are in serious condition, requiring intensive care then, which 
generated the need for units of high complexity and among them; there is the ICU [11].

Mobin and Salmito [12] research examined the air conditioners in ICU, since the pathogenicity of fungi allows us to put into practice prophylactic measures, decreasing nosocomial infections and the symptoms of ill building syndrome as pneumonia, rhinitis, allergic sinusitis, poor concentration, fatigue, both for patients and to other users of air conditionings.

In neonatal units in developed countries, overall rates of HI vary from 8.4 to $26 \%$. In Brazil, a tertiary level NICU has an infection rate from 18.9 to $57.7 \%$, having as reference causes for the high rates of infection: working conditions, physical structure of the NICU and number of nurses per bed [13].

This research aims to collect, identify and classify fungal contaminants in hospital units found in Adult and Neonatal High Complexity in the hospital area of high traffic (corridor) and outdoor area of a general hospital.

\section{Materials and methods}

The present study is an experimental research with qualitative and quantitative analysis of environmental contaminants present in 04 areas selected for this study, having as the criteria for inclusion the 02 units of high complexity, 01 central corridor for access to hospital departments and 01 outdoor area, such a choice was made because of potential risks to health and the environment in a hospital located in northern Paraná.

The research project was submitted along with the presentation letter to the Ethics and Research Committee (ERC) of the Undergraduate Program in Nursing at the University of Northern Paraná State - Luiz Meneghel Campus, number 098/2011, was approved by Opinion 082/2011 on December 20, 2011.

The air suction was performed through Microbiological Air Monitor M Air $\mathrm{T}^{\mathrm{TM}}$ - Millipore $^{\circledR}$ - (Merck SA) equipment for filtering the air in hospital environment, Mamizuka [14], report that a correct collection can be performed through solid systems that allow analysis and observation, after incubation of samples on the surface of the environment. There are several devices and equipment available on the market for collecting particles from the air in the form of collecting plates and sedimentation of particles from the air in order to detect the microbiological quality and quantity.

For this study we selected PDA (Potato, Dextrose, Agar), selected for fungi. Then we proceeded to the gravitational autoclaving for 20 minutes at a temperature of $121^{\circ} \mathrm{C}$ in order to maintain the sterility, thus avoiding growth of other microorganisms. After cooling, the culture media were identified and poured in sterile Petri dishes, with a protective cap for the culture medium, then sent to cooling. The preparation of culture media of tapes sent in hospital were transferred into culture medium and placed in refrigeration to be sent to the institution and attached to biomonitoring device at different collection points for seven minutes and sent back to the Microbiology Laboratory.

Then we proceeded to collect data in the hospital by sucking air, divided into four categories: 
1 - Adult Intensive Care Unit (High Complexity Unit)

2 - Newborn Intensive Carew Unit (High Complexity Unit)

3 - Corridor

4 - Outdoor Area

For comparative purposes of the microbiota present in the hospital environment, samples were collected from the corridor to the medical clinic units, as well as AICU and NICU. We decided also to collect ambient air in an area outside of the hospital, located between the main entrance to the Emergency Room (ER), canteen and access corridor between units of high complexity, because they are the entry areas for the institution and have increased movement of people. The collection took place in two periods: morning (10:00) and afternoon (15:00) with the Microbiological Air Monitor M Air TTM - Millipore $^{\circledR}$ - (Merck SA) Air filtration machine, generating quantitative results consistent to the reality of the hospital.

The time of collection was chosen so because of increased flow of people at times between 08:00 and 15:00, which was done trough the suction of the air by the machine Monitor Microbiological Air M Air T ${ }^{\mathrm{TM}}-$ Millipore $^{\circledR}-\left(\right.$ Merck SA) $^{\circ}$ for seven minutes, according to the specification contained in the manual procedure using the device distributed at three points of each area studied in both times, totaling 24 cassettes identified, packed and transported, observing the standards of biosafety in laboratories and health services.

During the gathering, the machine mentioned stood about a meter above ground level, as indicated by Lenzi et al. [15], in their research. The plates were exposed to air for a period of 5 minutes and then closed, with a total of 500L of air. After collecting ambient air, the tapes were stored in coolers with a safety device on the enclosure cover and sent to the laboratory of Microbiology at the State University of Northern Paraná (UENP) Luiz Meneghel Campus, incubated at $28^{\circ} \mathrm{C}$. The analytical stage was made through the quantification of the number of fungal colonies from the third to the sixth day of incubation, the number of colony forming units per $\mathrm{m}^{3}$ of air $\left(\mathrm{CFU} / \mathrm{m}^{3}\right)$ was used as a readout parameter and thereafter micro-organisms present in the air suspension hospital were isolated.

The results were obtained by counting microorganisms of each plate and subsequently calculated, a percentage of the total prevalence of microorganisms found. Then we applied the technique of microcultivation in order to preserve the original arrangement of spores and hyphae on some structures and keep intact spore-forming. We then carried out the identification of filamentous fungi by observation of colony morphology and microscopic aspects, with the analysis of the observation of colony color, texture and surface into the culture medium distributed in Petri dishes.

The results were analyzed using the Tukey test, which is an analysis of variance and multiple comparisons between means of experiments, using the Log base 10 and these are presented in Statistics 7.0 - SISVAR-DEX/UFL Program version 5.3. 


\section{Results and discussion}

The growth control was through daily monitoring and visualization (three times a day: morning, afternoon and evening), through identification of rounded strains, with aspects that varied from velvety, sandy and cotton - with different colorations.

The growth of micro-organisms was detected during monitoring, and the samples were separated and sent for identification on the bench. Plates in which bacterial growth was observed were collected and we then proceeded the counting for each colony forming unit. They were then sterilized in autoclave for 40 minutes and discarded in a proper place for disposal of biological materials. The Petri dishes that were to be reused again had to be cleaned and oven dried for an hour, and again packaged and sterilized by autoclaving for 30 minutes.

The Teaching and Research Laboratory of Microbiology follows the methodological procedures and respects all biosafety care in laboratory practices through the use of personal protective equipment (PPE) and collective protection equipment (CPE) [16, 17].

We analyzed all colonies of the fungi found in ambient air in both hospital units of high complexity (AICU and NICU), as well as the external environment, the corridor between the clinic medical - surgical areas (COR), and air samples external (EXT), entry service mobile emergency care (emergency) and canteen, whose numerical results are presented in Tab. 1.

Table 1: Air contamination by bacteria and fungi, expressed in absolute values(UFC) and transformed into (Log CFU) per $\mathrm{m}^{3}$.

\begin{tabular}{|c|c|c|c|c|}
\hline \multirow[b]{3}{*}{ ENVIRONMENT } & \multicolumn{4}{|c|}{ Fungi } \\
\hline & Morning & Afternoon & Morning & Afternoon \\
\hline & \multicolumn{2}{|c|}{$\mathrm{UFC} / \mathrm{m}^{3}$} & \multicolumn{2}{|c|}{$\log U F C / \mathrm{m}^{3}$} \\
\hline AICU & 23,3 & & $1.35 \mathrm{C}$ & $1.04 \mathrm{D}$ \\
\hline $\mathrm{NICU}$ & 55,3 & 30 & $1.73 \mathrm{~B}$ & $1.47 \mathrm{C}$ \\
\hline $\mathrm{COR}$ & 300 & 99,3 & $2.48 \mathrm{~A}$ & $1.99 \mathrm{~B}$ \\
\hline EXT & 304 & 198,7 & $2.47 \mathrm{~A}$ & $2.29 \mathrm{~A}$ \\
\hline
\end{tabular}

Averages following the same capital letter in the column do not differ in Tukey test $\mathrm{p}<0.05$.

Averages following the same lowercase letter in the line do not differ in Tukey test $\mathrm{p}<0.05$.

Data: UFC (Colony Forming Unit).

It was found that both in the afternoon as in the morning, the contamination was substantially lower in AICU $\left(23.3 \mathrm{CFU} / \mathrm{m}^{3}\right)$ followed with $55.3 \mathrm{CFU} / \mathrm{m}^{3}$ NICU. For Schwab et al. [18], the risk of contamination and transmission can occur by the presence of visitors in the neonatal unit.

In the hallway $\left(300.0 \mathrm{CFU} / \mathrm{m}^{3}\right)$ and external environment $\left(304.0 \mathrm{CFU} / \mathrm{m}^{3}\right)$ there was an equal amount of fungi in the morning but in the afternoon the amount was significantly higher in the external environment, tab.1. 
According to Resolution $\mathrm{N}^{\circ}$. 09/2003 of ANVISA, fungi are biological indicators of air quality, given that the recommended maximum value is $750 \mathrm{UFC} / \mathrm{m}^{3}$ of fungi [10].

The presence of fungi was significantly higher in the morning in three environments, which was not observed in the external environment where contamination was similar in both periods (fig. 1).

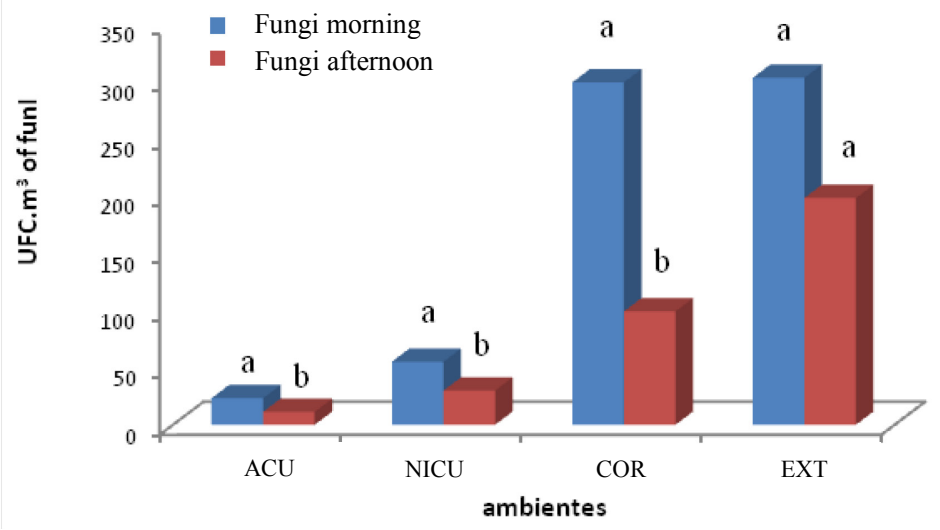

Figure 1: Analysis of air contamination in the environment by fungi.

To Brickus and Aquino Neto [19], the particle size is what determines its destination and can either hover, be deposited on surfaces or even inhaled by individuals causing harm to health.

In this study more contamination was found to occur in the morning, this could be related to increased air movement, visits by doctors and family and a greater number of nursing procedures. Also, it is during this period that daily cleaning is carried out aggravating indoor air contamination by fungi that remain suspended in the air for a longer period.

The results of the characterization, classification and identification of culture media replicated by microculture technique revealed the presence of 10 genera of filamentous fungi, and these, Alternaria sp, Aspergillus sp, Cladosporium sp, Curvularia sp, Fusarium sp, Helminthosporium sp, Mucor sp, Neurospora sp, Penicillium sp and Rhizopus sp (fig. 2).

From the 10 genera found, three genera were present in all environments and areas collected in all periods in the hospital, to be: Aspergillus sp, Penicillium $\mathrm{sp}$ and Fusarium sp, followed by Cladosporium sp and Neurospora sp, although not found during the morning in the NICU (fig. 3).

An important fact to be noted is the high diversity of fungi in the environment of the corridor and the NICU, where nine genera were identified from the total of 10. The fact of the diversity of fungi concentrate on internal environment (corridor) is due to the high influx of people coming from outside, and contaminants getting "trapped" in this space. The same was observed in the NICU, where there is high flux of mothers and health professionals and also because of higher humidity in the environment. 


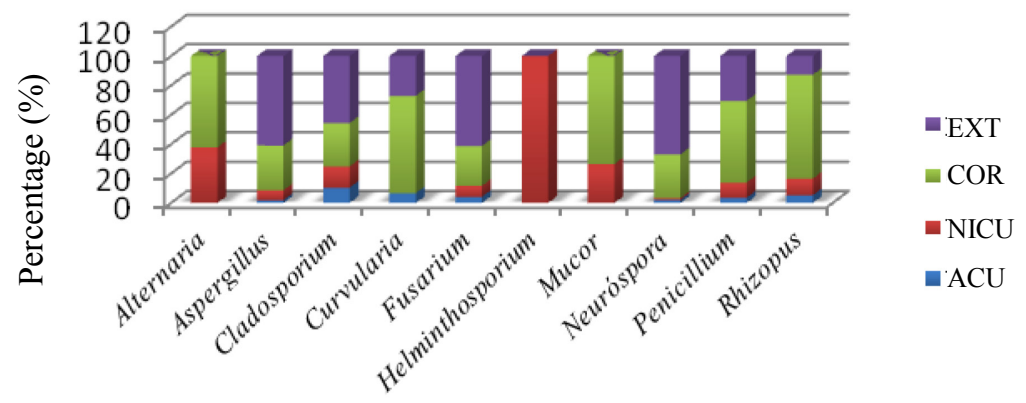

Figure 2: Percentage of relative genus of filamentous fungi, airborne contaminants in environments analyzed.

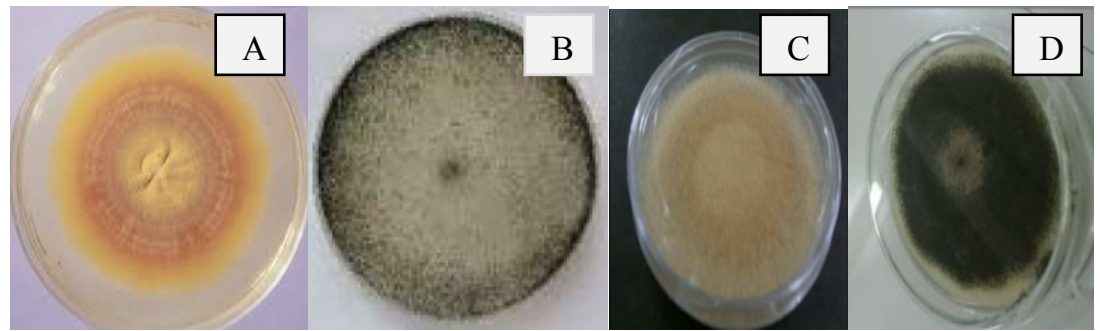

Figure 3: Main genera of air contaminant fungi in the environments analyzed.

(A: Fungus Helminthosporium sp; B: Fungus Fusarium sp;

C: Fungus Penicillium sp; D: Fungus Aspergillus sp.)

According to Quadros et al. [1], research, the genera most frequently found were: Aspergillus sp, Penicillium sp followed by Cladosporium sp, Trichoderma sp, Acremonium sp and Fusarium sp, and this result is quite similar to our study.

The genus Cladosporium sp stands out as being the largest concentration in the atmosphere with an optimum temperature range of $20-30^{\circ} \mathrm{C}$ with high concentration of spores [7, 20,21].

Costa [22], states that in large urban centers outside air has a large number of particulate material, i.e., material carried by the air, consisting of solid and liquid particles, microscopically small to the naked eye, this material being carried from outside to inside by people that go into the hospital environment, or even penetrated by openings in doors and windows as well as by the air conditioning system.

The relative percentage of fungi airborne contaminants concentrated predominantly in the outdoors and/or corridor, with the exception of the fungus Helminthosporium sp found only in the NICU (fig. 3), which can cause the oculomycoses, which are ocular mycoses caused by fungi, mostly in immunocompromised individuals [23].

The most common anemophilous fungi in Brazil belong to the genus Cladosporium sp, Penicillium sp, Aspergillus sp, Rhodotorula sp, Candida sp, 
Fusarium sp, Curvularia sp, Rhizopus sp, Trichoderma sp and Helminthosporium sp [23].

In Brazil, there is a small number of data concerning fungal microbiota in hospital settings because of the small number of studies that address this issue. For some time now, the incidences of fungal infections have been increasing gradually in immunocompromised individuals, leading to high mortality rates reaching up to $60 \%$ of deaths from HI. Fungal sepsis in neonates - babies of low birth weight, is becoming common in the neonatal period [8]. The results found in this study are in general agreement with those of other studies.

The genus Neurospora sp was one of the one of the most commonly found contaminants in this study. According to Rashmi et al. [24], the name of this fungus is due to its appearance of neuron and its color easily identifiable because of carotenoids, its color pigment orange or reddish.

Souza [9] mentions that some opportunistic fungi such as Penicillium sp, Aspergillus sp, Cladosporium sp, Fusarium sp and Candida sp are responsible for diseases such as otitis, micotoximicose, urinary infections, eye infections and onychomycosis and even fungemias. The author also states that an opportunistic pathogen is usually harmless in their normal habitat, but can become pathogenic in an individual who is weakened, traumatized or with his immune system compromised.

Lacaz [25], presents several anemophilous fungi, also known as contaminants may be found in dust and air, being allergenic. Therefore, numerous cases of asthma are associated with mycotic flora of air, yet the inhalation of spores, may cause coriza or conjunctivitis.

As described by Pannuti [26] and based on Etchebehere et al. [27], the genus Aspergillus sp is present in the hospital environment as being one of the first to be reported as a source of transmission of infectious agents, with predominance in the samples, both in the morning and in the afternoon.

Warris et al. [28], states that due to the small size of the spores of Aspergillus $\mathrm{sp}$, they remain in the air for prolonged periods, thus playing a crucial role in its spread in the environment and transmission to the patient. The findings of the genus Aspergillus sp are of great concern because this genus has a higher pathogenicity among the strains.

Costa [22], states that the genus Aspergillus fumigattus is the main agent responsible for infections, being most frequently found outdoors. Its spores are propagated through the air, due to the fact of their size being between 2 and $3 \mu \mathrm{m}$ diameter, facilitating inhalation by immunocompromised patients, with the possible death of the patient.

The spores of Penicillium sp and Aspergillus sp can be found in all rooms, with great distribution and causing infections especially in immunocompromised individuals $[22,29]$.

Gambale et al. [7] mention that among the various genera of fungi, Cladosporium sp is considered to be one of the most cosmopolitan, with a large concentration in the atmosphere in temperate regions and play a significant role among the fungi that cause harm to the respiratory system [30]. 
The genus Alternaria sp is considered an opportunistic fungus and has been found in skin lesions, osteolytic lesions and onychomycosis in immunocompromised patients [31].

\section{Conclusion}

In the course of this research, the proposed aims were achieved, and it has emphasized the seriousness and concern of HI concerning the hospital air to which people are exposed.

In none of the environments studied the average concentration of filamentous fungi exceeded the maximum recommended by Resolution RE $\mathrm{N}^{\circ}$. 09 of 750 CFU $/ \mathrm{m}^{3}$ ANVISA [9].

We identified 10 genera of filamentous fungi airborne contaminants, some pathogenic and/or toxigenic and three genera were present in all environments of the areas to be surveyed: Aspergillus sp, Fusarium sp and Penicillium sp.

The study highlights the high diversity of fungi in the corridor and NICU environments, identifying in these areas 09 of total 10 genera found.

The awareness about cleanliness and hygiene must be present in all activities involving hospital practices, mainly in ICU and other High Complexity areas.

\section{Final considerations}

It is necessary that the agents who make the hospital environment raise awareness to the adoption of effective measures in order to promote a more hygienic, healthy and safe hospital environment. To do so, it is important to enforce the present legislation together with the daily efforts for the benefit of all.

\section{Acknowledgements}

This research project was supported by the Director of Direct UENP - Luiz Meneghel Campus - Bandeirantes/PR - Brazil. We would like to thank Millipore Company ${ }^{\circledR}$ - Brazil (Merck SA), for the granting of environmental biomonitoring equipment.

We especially thank the Laboratory of Microbiology at the State University of Ponta Grossa which promoted exchange of technical and scientific knowledge. We also thank Carmen A. Caramori Fontes, translator, for text revision and language translation.

\section{References}

[1] Quadros, M. E. et al. Qualidade do ar em ambientes internos hospitalares: estudo de caso e análise critica dos padrões atuais. Eng. Sanit. Ambient. v. 14, n.3. p. 431-438. jul./set.2009. 
[2] Andrade, D. A., Angerami, E. L. S. Reflexões acerca das infecções hospitalares às portas do terceiro milênio. Medicina, Ribeirão Preto, v. 32, p. 492-497, 1999.

[3] Brasil, Ministério da Saúde. Portaria nº 2.616 de 13 de maio de 1998. Regulamenta as ações de controle de infecção hospitalar no país. Diário Oficial da República Federativa do Brasil, Seção I, 15 maio 1998.

[4] World Health Organization. Indoor air quality: biological contaminants. Rautavara, 1998.

[5] Andrade, D., Leopoldo, V. C., Haas, V. J. Ocorrência de Bactérias Multiresistentes em um Centro de Terapia Intensiva de Hospital Brasileiro de Emergências. Rev. Bras. Terap. Intens. v.18, n.1. p. 27-33, jan./mar. 2006.

[6] Oliveira, A. C. et al. Infecções Hospitalares: epidemiologia, prevenção e controle. Rio de Janeiro: MEDSI, 2005.

[7] Gambale, W, et al. Library fungi at the University of São Paulo and their relationship with respiratory allergy. J Invest Allergol Clin Immunol. 3(1):45-50, 1993.

[8] Sidrim, J. J. C, Rocha, F. G. Micologia Médica à luz de autores contemporâneos. Rio de Janeiro: Guanabara Koogan, 2004, 388p.

[9] Souza, A. K. P. Microbiota Fúngica do Ambiente da UTI Neonatal e de Amostras Clínicas dos Recém Nascidos Internados no Hospital Universitário de Maceió, AL. Dissertação de Pós - Graduação. Universidade Federal de Alagoas - Ciências da Saúde do Instituto de Ciências Biológicas. Maceió, Alagoas. Brasil, 2009, 128p.

[10] Brasil, Ministério da Saúde. Agência Nacional de Vigilância Sanitária. Resolução $\mathrm{n}^{\circ} 09$ de 16 de janeiro de 2003. Determina a publicação de Orientação Técnica elaborada por Grupo Técnico Assessor, sobre padrões referenciais de Qualidade do Ar Interior, em ambientes climatizados artificialmente de uso público e coletivo. Diário Oficial da União. Poder Executivo, de 20 de janeiro de 2003.

[11] Saraiva. C. A. S. Tese de mestrado emengenharia: Fatores Físicos Ambientais e organizacionais em uma unidade de terapia intensiva neonatal: implicações para a saúde do adulto. Porto Alegre, 2004.

[12] Mobin, M., Salmito, M. do A. Microbiota fúngica dos condicionadores de una unidade de terapia intensiva de Teresina, PI. Revista da Sociedade Brasileira de Medicina Tropical 39(6): 556-559 nov-dez, 2006.

[13] Margotto, P. R. Prevenção da infecção neonatal na uti neonatal: novos desafios. $5^{\circ}$ Simpósio Internacional de Neonatologia do Rio de Janeiro, 28 30 se set 2006.

[14] Mamizuka, E. M. Manuseio, Controle e Descarte de Produtos Biológicos. In: Hirata, M. H., Filho, J. M. Manual de Biossegurança. 1. ed. São Paulo: Manole, 2012, p. 87-107.

[15] Lenzi, F. S, et al. Qualidade do ar em diferentes ambientes do Hospital Regional de São José (Trabalho de conclusão de disciplina - graduação em Engenharia Sanitária e Ambiental). Florianópolis: Universidade Federal de Santa Catarina: 2007. 
[16] Skraba, I., Nickel, R., Wotkoski, S. R. In: Mastroeni, M. F. Biossegurança aplicada a laboratórios e serviços de saúde. 2. ed. São Paulo: Atheneu, 2005.

[17] Mastroeni, M. F. Biossegurança aplicada a laboratórios e serviços de saúde. 2. ed. São Paulo: Atheneu, 2005.

[18] Schwab, F., Tolbert, B., Bagnato, S., Maisels, J. Sibling visiting in a neonatal intensive care unit. Pediatrics; 71: 835-8, 1983.

[19] Brickus, L. S. R., Aquino Neto, F. R. A qualidade do ar de interiores e a química. Quimica Nova; 22(1): 56-74, 1999.

[20] Sabariego, S., Diaz de la Guardia, C., Alba, F. The effect of meteorological factors on the daily variation of airborne fungal spores in Granada (southern Spain). Int. J. Biometeorol. (44), p.1-5.

[21] Menezes, E. A., Alcanfor, A. C., Cunha, F. A. Fungos anemófilos na sala de periódicos da biblioteca de ciências da saúde da Universidade Federal do Ceará. $R B A C,(38):$ p.155-158, 2006.

[22] Costa, M. R. Recomendações para o controle da qualidade do ar climatizado. Goiania, Brasil, março 2007.

[23] Lacaz, C. S, Porto, E, Martins, J. E. C. Micologia Médica. 8 ed. São Paulo: Sarvier, 2002, 695p.

[24] Rashmi, K., et al. Neuróspora in full Bloom. Current Science, v.85, n.12 p. 2003.

[25] Lacaz, C. S. O Grande Mundo dos Fungos. São Paulo, Editora da Universidade e Editora Polígono, 1970, 248p.

[26] Pannuti, C. S. A importância do ambiente hospitalar. In: Rodrigues, E. A. C. et al. Infecções Hospitalares: prevenção e controle. São Paulo: Savier, 1997. p. 449-454.

[27] Etchebehere, A., Servilieri, K. M., Regazzi, R. D., Pedroso, M. Z., Sartorelli, E. M., Carlos, A. L., Nabeshima, M. A., Cardoso, M. M., Nunes, N. R. da S., Dias, T. Metrologia participa do controle de infecções hospitalares cuidando da qualidade do ar. Simpósio de Metrologia na Área da Saúde. Rede Metrológica do Estado de São Paulo. São Paulo, Nov. 2005.

[28] Warris, A., Voss, A., Verweij, P.E. Hospital sources of Aspergillus: New routes of transmission. Rev. Ibero Am Micol: 18: 156-62, 2001.

[29] Moghazy, N. E. H. E. Penicillium as an Indicator of Hospital Fungal Airborne Contamination. Faculty of Medicine Ain Shams University, 5.p. 2008.

[30] Myszkowska, D. et al. The relationship between airborne pollen and fungal spore concentrations and seasonal pollen allergy symptoms in Cracow in 1997-1999. Aerobiologia; 18: 153-61, 2002.

[31] Lacaz, C. S, Porto, E, Hoins-Vaccari, E. M. Guia para identificação: fungos, actinomicetos e algas de interesse médico. São Paulo: Sarvier; 1998. 